\title{
Genesis and Development of Religious Fundamentalism: Socio-philosophical Aspects
}

\author{
Alexey Volobuev \\ Department of Sociology \\ Financial University under the Government of the Russian Federation \\ Moscow, Russia \\ E-mail: urticaferox@yandex.ru
}

\begin{abstract}
The article deal with the analysis of social and philosophical aspects of the complex and ambiguous phenomenon of religious fundamentalism. The formation and development of this trend can be traced, not in the chronological order of the emergence of fundamentalist trends within the framework of various religious traditions, but in the process of understanding fundamentalism as an independent phenomenon of religious studies and political thought. The article analyzes the origination of religious fundamentalism in the United States, the formation and development of Islamic fundamentalist trends, manifestations of fundamentalism within other traditions, and their politicization and intertwining with other socio-political processes. The article reveals the essence of fundamentalism in the context of the process of globalization. The author demonstrates that fundamentalism as a whole is not synonymous with traditionalism but is one of the possible responses of religious consciousness to the rapid process of modernization.
\end{abstract}

Keywords-religion; fundamentalism; Islam; evangelical churches; philosophy of religion; religious studies; modernization

\section{INTRODUCTION}

Modern social and political events attract the public's attention to the phenomenon of religious fundamentalism. The news media regularly reports various terrorist acts committed by Islamic fundamentalist groups, and publicists talk about the dangers of fundamentalism. Even those in academic positions often hold the same positions. Thus, Anthony Giddens, professor at the London School of Economics and Political Science, characterizes the fundamentalist "... as a person who in principle refuses to enter into a dialogue, who considers his way of life to be perfect and worthy, and a foreign one - relatively inferior and unworthy". And, he cautiously adds, "This is very dangerous: the more we have to live in a world where it is necessary to get along with people who are not like us, the more dangerous this principle is becoming." [1]. How can such a phenomenon be possible in the modern world of rapid progress and what does it mean? In order to find an answer to these questions, it is necessary to examine the formation and development of religious fundamentalism, highlighting its socio-philosophical aspects.
As a rule, the emergence and development of some new ideology will soon lead to the emergence of an oppositely directed one. In the Age of Enlightenment, the ideas of progress, modernization, and modernizing all aspects of life have already shaped the ideology of modernity; these include the desire to modernize religion. The key messages of the latter were the desire to purge religions of superstition, singling out the "rational" grain in them. First of all, ethics was examined. It should be noted that religious modernization was not limited to the Christian world Islamic religious reformers, such as Mohammed Iqbal, began to exert a significant influence on contemporary society in the $19^{\text {th }}$ century. The opposite tendency, which meant resisting any changes in the religious life of society and returning to its hypothetical "initial" state, took shape somewhat later.

Religious fundamentalism is often identified with traditionalism. This is completely untrue, despite some intersections between the two concepts. If traditionalism is associated with the desire to preserve what is available, fundamentalism is based on longing for what has already been lost and for renewal through a return to the roots.

\section{THE ORIGINATION OF FUNDAMENTALISM}

It is generally accepted that the notion of "fundamentalism" appeared in the second half of the nineteenth century in American religious studies to denote the position of those members of evangelical churches who did not accept the liberal interpretation of the Bible and the modernization of Christian doctrine. American fundamentalists became widely known for their intransigent struggle against evolutionary principles, especially after the adoption of the Butler Act (1925, Tennessee, USA), which prohibited the teaching in schools and universities of any non-biblical theories of human origin, in particular, the theory of evolution. What are the key features of fundamentalists, which allows them to be grouped as a separate trend?

First, they recognized the sacred texts as the source of absolute and infallible truth. In particular, the fundamentalists insisted on a literal interpretation of the Biblical miracles, believing that the sacred text contained a pristine truth, and not accepting the allegorical 
interpretations of the modernists. P. S. Gurevich cites the words of one of the ideologists of this movement, D. Fellwell, "The fundamentalist believes that the Bible was in the literal sense inspired by the Holy Spirit and therefore it is infallible. Fundamentalists believe in the deity of Jesus Christ. They readily acknowledge his virgin status, sinless life, death for redemption. The fundamentalist believes in evangelism and apprenticeship through the local church as a proper exercise of the great mission of our Lord" [2].

Second, they were inclined to a rigorous, "black and white" perception of the world, considering themselves participants in the struggle between good and evil in a very literal sense, or, for example, sharing the view that the course of history is predicted in biblical prophecies.

Third, the fundamentalists were distinguished by a very aggressive, militant attitude toward any manifestations of the modernization of religion (both theology and social life) and by the tendency to demonize their opponents. They considered themselves to be "true Christians of biblical faith."

It should be noted that the anti-modernist attitude of the American Evangelical churches had a significant impact on the entire Protestant segment of American society (i.e., on almost the whole society): "In the US, there is a very fundamentalist society, similar in degree of religious fanaticism to Iran. For example, seventy-five percent of the US population, I think, simply believe in the devil," sums up Noam Chomsky [3]. Thus, religious fundamentalism appeared in the US as a reaction to the modernization of theology and religious life from some members of the Evangelical churches. This was not simply a rise in traditionalism; fundamentalism shaped its own paradigm and self-identification system.

\section{DEVELOPMENT OF FUNDAMENTALISM}

The next milestone in the development of fundamentalism can be called its access to the geopolitical arena as the official ideology of a large state. It happened after the Islamic revolution in Iran in 1978. Here we see a new round of the development of fundamentalism, which had evolved from a worldview position on the interpretation of sacred texts into a powerful political ideology. Since 1978, fundamentalism has been actively studied not only by religious scholars; the attention of political scientists around the world was also attracted to this phenomenon which, at first glance, does not fit into the positivist picture of the development of society.

It is Islamic fundamentalism, ("vusulia"), which, as a rule, is at the center of attention of public consciousness and scientific examination when it comes to fundamentalism in general. Of particular interest to religious scholars and political scientists is its Salafi form (from Arabic "as-salaf" "ancestors"), the ideological basis of the vast majority of modern Islamist trends and organizations. Salafism is more than a theological school; it is the totalitarian political ideology of a theocratic state. "The slogan al-Islam hua alhal" ("Islam is the solution") means that in order to restore order in the Muslim world, to eradicate social injustice, immorality and corruption, to eliminate "unjust rulers", as well as to protect against the harmful effects of foreign cultural and behavioral models of the West, it is necessary, first of all, to purify Islam itself from harmful layers, to return to the unclouded origins of this religion" [4].

Salafists of the most diverse kinds proceed from the common belief that the Islamic world is in a state of decline caused by the retreat from traditional values and ethics of Islam and the Islamic Sharia, the rejection of the Islamic ethical and legal system. Fundamentalists demand a return to the laws, norms, and values of Islam, thus building a socially just state. At the same time, fundamentalists often gravitate toward a kind of pan-Islamism, because the Islamic state must unite the disparate national entities of the Islamic world or even the entire Muslim community, the umma. Thus, the ideology of Islamic fundamentalism draws its energy primarily from the acute social injustice inherent in a globalized world and increasingly growing in a society of high consumption, where the rich are becoming richer and the poor are becoming poorer.

In general, Islamic fundamentalism is composed of a colorful palette of different currents and doctrines of various beliefs and degrees of aggression. Perhaps the most influential, radical, and extremist fundamentalist trend in Islam can be called Wahhabism, which arose among nomadic Bedouins of the Arabian Peninsula and which has spread its influence throughout the Muslim world. The core of the ideology of Wahhabism is the purification of Islam from all doctrinal innovations and the return to Islam in its "original", i.e. "pure" form; Wahhabism is fundamentalism in its uncompromising form. A striking feature of Wahhabism is extreme intolerance towards representatives of other faiths, atheists, and even those Muslims who do not practice "pure" (from the point of view of Wahhabis) Islam, for example, to representatives of numerous Sufi trends. At the same time, the only acceptable form of power for Wahhabis is a government which strictly follows the laws of Sharia in the interpretation of the traditional Khanbalit mazhab.

There is a significant difference between the fundamentalism of American evangelical churches and Islamic fundamentalism: the former is a position on the interpretation of sacred texts and it is more philosophical in nature, whereas the latter is primarily a political ideology. Why do two essentially different phenomena have the same name? The reason is that the conceptual design of the term "religious fundamentalism" was given to it about a century after its appearance. One of the famous models of religious fundamentalism was proposed by a theologian, M. Marti, and a historian, S. Appleby, in the five-volume edition of "Fundamentalist Project". In this work, the following characteristic of fundamentalism is given: it is a confrontation of modernization, secularization and rationalization, which "wants to replace the existing structures with a comprehensive system based on religious principles and encompassing the law, the state, the society, the economy, the culture" [5]. 
As for Islam, in the very structure of this nomocratic system as a whole, it is possible to see the "seed" of fundamentalism, ready to "germinate" due to its abundant "watering" with the flood of changes. A significant portion of the fuqaha (Islamic religious and legal figures; the term can be roughly translated as "theologian") tend to understand by religious renewal the process of returning to the origins, that is, the foundations of faith. It is very common idea that the key to solving many actual problems of our time lies in the study of the Quran and the Sunnah, and the cause of problems, failures, and lawlessness is the appearance of a large number of innovations - bida.

The latter term, due to its importance, requires special analysis. This term denotes innovation, i.e., innovations in life, errors in knowledge, or a solution that was not in the Quran and the Sunnah. It is characterized very negatively. "The worst acts are the newly invented ones, and each such act is an innovation, and every innovation is a delusion, and every error in the Fire!" [Muslim 2/592, en-Nasai 3/188]. Mistrust and a negative evaluation of innovations, as a rule, is interpreted as relating only to religious doctrine. This fragment encourages the Muslim to follow the Sunnah and warns against innovations in religious life that are divergent from the Quran and the Sunnah. But the hadeeth itself leaves a wide field for interpretation; as a result, this widely known text itself lays a specific foundation for fundamentalism. For many ideologists of Islam, who dealt with the challenge of modernization, there was a great temptation to use the hadeeth to reject modernization and Westernization as a harmful innovation for society, by "proscribing" a fundamentalist "recipe" for the Muslim society which is "sick" because of changes, this recipe being: forward, into the past! As all the problems of society are caused by harmful innovations, it is necessary to recall those times when these problems did not exist and to return the Muslim community to its idealized pristine condition.

In Russian history, there was a similar process, which occurred earlier in the times of schism. As the Russian Orthodox Church faced the challenges of modernization and Westernization, the response from church hierarchs was energetic reforms. They were aimed at a renewal of religious life through its rationalization, centralization, significant investments in infrastructure, inspiration of new energy in it, and struggle against "disorganization" and archaisms. Exceptionally energetic reforms of Patriarch Nikon caused an extremely negative reaction in a part of society; the response of consciousness to the flow of change was the flight from these very changes, that is, the flight of the Old Believers into an idyllic past. Raskolniki in Russian history are very similar to religious fundamentalists.

Modern Russian Orthodoxy also has certain features of fundamentalism. This is both anti-ecumenism and extreme statism: the ROC opposes the Russian state identification with the abstract model of the "sinful" West, and features a general attitude of opposition to the liberal socio-political model of a globalized society, especially to the market economy with its social injustice [6].
Fundamentalism always promises a return to the "roots". Why is Orthodox fundamentalism trying to get people to go back? First of all, there is a return to the social and messianic concepts of the monks Filofey and Danilevsky. Being deeply state-minded, Orthodox fundamentalism pushes the Orthodox society to an active position in political life. Political science concepts are borrowed and intertwined into the domain of a fundamentalist worldview. For example, according to Patriarch Kirill, "We are in favor of a multipolar world, by which we understand not only the poles of political power, like a lot of politicians do, but it is the coexistence of civilizational models" [7].

\section{FUNDAMENTALISM AND POLITICS}

Religious fundamentalism is a complex and multifaceted phenomenon, originating from religion, but not limited to it: fundamentalism contains a powerful socio-political component. The fundamentalists emphasize, as a rule, the need for manifestations of an active civic stand by members of their movement: practically all representatives of American Evangelical churches, who called themselves (and call themselves today) fundamentalists, considered it unacceptable to be out of public activity. Since 1979, religious fundamentalism, which emerged as a single phenomenon, can be divided into theological and political. The evangelical follows the first type, while Salafism, for example, adheres to the second one.

But why is fundamentalism, unlike traditionalism, a phenomenon related to modernity? The reason is because the fundamentalists not only strive to preserve their way of life (like the "Old Believers"), they create and preach their ideal of life, which they put in the past, thus creating a kind of "false memory" of an idealized past. Then the fundamentalists seek to extend it to the modern society through propaganda in the media. That is why fundamentalism is inclined to become a political ideology. Fundamentalism is not a direct antithesis to modernity. On the contrary, fundamentalists borrow from modern times those means which are considered necessary to achieve their goals.

"Fundamentalism is by no means synonymous with the term 'traditionalism', it is rather one of the possible ways of renewing tradition. It combines the reworked, idealistically presented elements of tradition and innovation to such an extent to which they are necessary to establish the ideal. Fundamentalism is related to Tradition, but it is not limited to it, it is always the answer of the mythologized Tradition to the challenge of Modern Time" [8]. Thus, there is no contradiction in the fundamentalists' use of rational thinking, media, and modern technologies. Likewise, there is no contradiction in the striving to acquire material wealth and power for the sake of an ideal goal. "Thus, religious fundamentalism and religious modernism are ambivalent phenomena which are able to actively interact with each other and come together in their content" [9].

Since fundamentalism views social injustice, corruption, and lawlessness as inherent features of modernization and globalization, this ideology turns out to be an expression of 
social protest of the masses. For example, one of the representatives of modern Christian fundamentalism, G. Kyung, wrote: "The idols of modern times (science, technology and industry) largely discredited themselves, and therefore, in the name of humaneness of man and for life on earth, they must be subordinated to moral responsibility and put under moral control" and "the great god of modernity, bearing the name of 'progress', was exposed as a false deity, and now the call for a true God is becoming more and more loud, not only within the framework of Christianity ..."[10].

An important question remains to be examined: How are fundamentalist ideas compatible with liberal values? The basic tenet of liberal democracy, the demand for obedience to the will of the majority, directly contradicts the ideology of Islamic fundamentalism: "They do not vote for God, they obey God" [11]. But the absence in fundamentalist ideologies of any productive social and economic program that transcends the redistribution of wealth makes possible the integration of liberal values even into the consciousness of a religious person, since this lacuna is not filled with Islamic ideology. Thus, a balanced religious policy aimed at supporting the moderate and discrediting extremist trends of Islamic fundamentalism allows directing the social protest of the marginalized masses of the population into the traditional religious channels, while coping with dangerous extremist tendencies, especially support for radical Salafi trends from abroad.

However, the socio-political role of fundamentalism is not necessarily restricted to radical and extremist movements. Thus, among the Islamic fundamentalist organizations, there are those preaching peaceful policies and charities. For example, "the Organization of Islamic Cooperation (OIC), which opposes racism and colonialism, RAIS (Russian Association of Islamic Consensus) and OIC (Organization of Islamic Cooperation), which work for the unity of Muslims through good deeds (establishment of the Fund for Assistance to Victims of Extremists, construction of mosques, work with youth, etc.)", as well as numerous charitable organizations [12].

In addition to the socio-economic prerequisites of fundamentalism, one can also characterize its sociopsychological prerequisites. The process of globalization blurs the boundaries of the subjective space, providing subjectively unlimited opportunities, but at the same time destroying the sense of security, the source of which is identity, which is closed in the space of a community, nation, ethnos or religious group. But globalization blurs the boundaries of subjective space, "fencing" identity, thus destroying this feeling. In the era of extremely rapid changes, the direction of which is incomprehensible to man, and the destruction of traditional axiological systems which destroys his value system of coordinates, a significant number of people seek to restore the identity as a "comfort zone". An individual thus gets the opportunity to identify himself through serving abstract goals defined by a certain fundamentalist system of values. He socializes through identity, and thereby rids himself of the sensation of "squirrels in the wheel", which condemns a person to eternal dissatisfaction.
It should be noted that fundamentalist psychology turns away from a cultural dialogue. Thus, fundamentalism plays two conflicting roles: culture and counterculture. This contradiction is resolved in a simple way: fundamentalism is a counterculture for a globalized unified culture, but at the same time strives to become the mainstream local culture. For example, Orthodox fundamentalism separates from the "Orthodox world", opposing it in the rest of the world.

\section{CONCLUSION}

Proceeding from the foregoing, we can draw the following conclusions. First, religious fundamentalism is not a synonym for traditionalism, but is a political ideology and an aggressive reaction to the modernization and rationalization of religious life and society. The essence of this reaction lies in the fact that, in today's disequilibrium society of risk, turbulence, and open future, religious fundamentalism presents a simplified alternative. This takes the form of abandoning modernization as such, seeing the future through an idyllic simplistic picture that supposedly had a place in the past. Instead of unraveling the complex tangle of social and economic problems, fundamentalism puts forward the idea of returning to the previous state of society when these problems simply did not exist. "Islam is the solution!" is one of the popular slogans of the Islamist organization "Muslim Brotherhood".

Second, the social and psychological foundation of fundamentalism is the reaction of the consciousness, lost in an enormous globalized world, to an open, rapidly changing world. Where open competition prevails, the risks are extremely high, and all responsibility for making a decision (and just a lucky or unfortunate coincidence) is not damped by community or traditional values but is entirely on the shoulders of the individual. Fundamentalism as a whole is a reaction to the processes of globalization and secularization that are taking place in modern society. As a sociocultural phenomenon, modern fundamentalism is the reverse of the process of globalization and Westernization. Its context is secularization as the liberation of man and society from the spiritual monopoly of clergy and religious dogmas continues. This is seen in the decline of religious institutions, the erosion of traditional value systems, and the loss by ethics of its dominant position in the socialization of man. Religion in a globalized culture loses its institutional isolation and passes into the realm of personal experiences. In contrast, fundamentalism returns to it the lost role of the social and political institution.

The cultural component of fundamentalism is also significant. "So, the cultural nature of fundamentalism is in resisting the increasing complexity of life and its renewal. From this point of view, it is possible that the fundamentalist tendencies of culture are constantly inspired by another extreme. If there was no culture of an inescapable, desperate pursuit of innovation, fundamentalism would not show up in its intrusively directive forms. In the same way, modernism draws its strength in opposing all orthodoxy, protection, social statics" [13]. 
Third, the relationship of fundamentalism to science in general and scientific and technical progress in particular, is surprisingly flexible. On the one hand, fundamentalism openly confronts scientism and many basic scientific theories, such as the theory of evolution but, on the other hand, it calmly accepts other achievements of scientific and technological progress.

Fourth, fundamentalism does not merely claim to "return to the roots" in the religious tradition; it is a return to premodern, syncretic thinking where various aspects of life politics and religion, private and public life, faith and reason - often did not have a clear division. Therefore, fundamentalism does not see itself outside the public and political life. Often, fundamentalism considers it necessary to restructure society in all its manifestations in accordance with the ideal of its tradition. Again, we can cite the slogan "al-Islam hua al-khal" ("Islam is the solution").

Another element of syncretic thinking is associated with the antithesis "sacral - profane". Modernization has consistently removed the sacredness from almost all spheres of life, trying, however, to replace it with human rights and freedoms as sacred values. But the success of this replacement raises great doubts. A fundamentalist often perceives desacralization as desecration and he demands to return its former status to the sacral. "The main line of confrontation between the influence of Western modernity and Islamic antimodernism lies along the axis of "secularization (profanization) - re-sacralization of society" [14].

Fundamentalism in the modern globalized world is not an anachronism. On the contrary, it is one of the forms of adaptation of society to the rapidly changing conditions of public life. Fundamentalism will probably always be the "reverse side" of globalization, and without exploring and understanding it, the picture of the contemporary world will never be complete.

\section{REFERENCES}

[1] A. Giddens, What tomorow: fundamentalism or solidarity // Patriotic scripts. 2003, № 1. URL: http://www.strana-oz.ru/2003/1/chtozavtrafundamentalizm-ili-solidarnost

[2] P. S. Gurevich, Fundamentalism and modernism as cultural orientations. Social sciences and modern time. 1995, No.4, pp. 154162 .

[3] N. Chomsky, How the world works. Moscow, AST, 2014, 448 p.

[4] G. I. Mirsky, Political Islam and the Western society. Polis, 2002, No.1, pp. 78-86.

[5] M. E. Marty and S. R. Appleby, Conclusion: An Interim Report on Hypothetical Family. The Fundamentalism Project. Chicago, 1991, vol. 1, p. 824.

[6] E. A. Stepanova, Fundamentalism and the identity mania. Annual scientific magazine of the Institute of philosophy and law of Ural section of RAS. 2008, No. 8, pp. 94-116.

[7] Interfax: religion.ru/orthodoxy/index.php?act=news\&div=21331

[8] A. I. Yakovlev, Religious factor of international policy in the globalization era: from secularization to fundamentalism. Moscow University Herald, S.25. International relations and global policy. 2013, No. 4, pp. 4-37.
[9] D. A. Golovushkin, Religious fundamentalism/ religious modernism: conceptual enemies or ambivalent phenomena? PSTGU Herald I: Theology. Philosophy, 2015, No. 1(57), pp. 87-97.

[10] G. Kung, Great Christian thinkers. SPb, Aleteya, 2000. 442 p.

[11] M. Kramer, Where Islam and democracy part ways. Democracy in the Middle East: Defining the Challenge. Washington, 1993, p.257.

[12] I. S. Shegaev, Religious fundamentalism: definition and origins Almanac of modern science and education. Tambov: Gramota, 2014. No.1(80), pp. 133-136.

[13] P. S. Gurevich, Fundamentalism and modernism as cultural orientations. Social sciences and modern time. 1995 , No. 4, pp. $154-$ 162.

[14] S. I. Chudinov. Antimodernism in the ideological systems of modern Islamic thought: from ontologisation of ethnicity to resacralisation of the state. Islam in the modern world. Islamic studies, 2015. Vol. 6. №2(24), pp. 38-49. 